\title{
Characteristics and geological significance of germanium in Taiyuan coal formation of Huainan Coalfield, Anhui, China
}

\author{
Dun Wu ${ }^{1,2,3} \cdot$ Wenyong Zhang ${ }^{2,3} \cdot$ Guijian Liu ${ }^{1,3} \cdot$ Run Zhan ${ }^{2,3} \cdot$ Guangqing Hu ${ }^{1,2,3}$
}

Received: 29 December 2019/Revised: 30 June 2020/Accepted: 4 November 2020/Published online: 24 November 2020

(C) The Author(s) 2020

\begin{abstract}
HN-1\# is the first fully working coring well of the Taiyuan Formation (Ty) in the Huinan Coalfield and exploration studies are currently underway on the associated resources of the coal-bearing strata. The HN-1\# well is located in the Fufeng thrust nappe structural belt in the south of the Huainan Coalfield. Three coal samples from the Ty were collected from HN-1\# and inductively-coupled plasma mass spectrometry and inductively-coupled plasma atomic emission spectrometry were used to determine the Ge content of each sample. Based on proximate and ultimate analyses, microscopy data, and analyses of the ash products, some important findings were made. The Ty coal samples had a relatively high total sulfur $\left(\mathrm{S}_{\mathrm{t}, \mathrm{d}}\right)$ content $(4.24 \%)$, thus the coal was considered to be a lower ranked coal (high volatility bituminous coal), which also had a low coal ash composition index $(k, 1.87)$. Collodetrinite was the main submaceral of the Ty coal. Small amounts of pyrite particles were found in the coal seams of the Ty, while the contents of pyrite and algae in the top and bottom sections of the coal seam were relatively high, which meant that the swampy peat conditions which existed during the formation of the coal seams were affected by seawater; also the degree of mineralization of the coal seam was relatively high, which is consistent with reducing conditions in a coastal environment setting. Atomic force microscopy (AFM) experiments showed that the modes of occurrence of Ge in the Ty coal were mainly those for organic-bound and adsorbed Ge species. The organic carbon isotope values for the Ty coal ranged from $-24.1 \%$ to $-23.8 \%$, with an average value of $-24.0 \%$, which is equivalent to the value for terrestrial plants (average value $-24.0 \%$ ). The Ge content of the Ty coal was $13.57 \mathrm{mg} / \mathrm{kg}$. The Ge content was negatively correlated with volatile matter and the ash yield.
\end{abstract}

Keywords Germanium · Modes of occurrence $\cdot$ Chemical species · ICP spectrometry · Taiyuan coal formation · Fufeng thrust nappe structural belt $\cdot$ Huainan Coalfield

\section{Introduction}

Exploration studies on mineral resources in coal basins and coal measures continue at pace given the increasing eco-

Wenyong Zhang

adam854621@163.com

$\square$ Guijian Liu

lgj@ustc.edu.cn

1 School of Earth and Space Sciences, University of Science and Technology of China, Hefei 230026, Anhui, China

2 Exploration Research Institute, Anhui Provincial Bureau of Coal Geology, Hefei 230088, Anhui, China

3 Anhui Province Green Mine Engineering Research Center, Hefei 230088, Anhui, China nomic importance of strategic mineral resources including those in coal measures (Shao et al. 2020). In particular, the enrichment and mineralization of rare earth elements related to coal and coal-bearing strata has become one of the research hotspots in current coal geology (Seredin and Finkelman 2008; Dai et al. 2010, 2012a, b; Seredin and Dai 2012; Seredin et al. 2013; Dai et al. 2014, 2016). Alongside the development of emerging industries, the demand for metallic mineral resources in high-tech fields has become increasingly important. The unique reduction properties 
and barrier properties of coal can act to enrich some metallic elements (rare earth elements and precious metals) in coal under specific geological conditions (Dai and Ren 2007). Among these elements, germanium (Ge) is a rare metallic element. With the emergence of high purity $\mathrm{Ge}$, a large number of $\mathrm{Ge}$ semiconductor devices have been developed, and this has stimulated rapid development of the modern electronics industry. At present, Ge is not only used as a key semiconductor component in computers, missiles, and space technology, but is also widely used in new technical fields (Zhang et al. 2006). Up to now, no single Ge ore body has been found to satisfy the worldwide demand for this strategic element. Coal is known to contain a considerable amount of Ge, and is currently an important source for $\mathrm{Ge}$ processing and utilization (Hower et al. 2013).

Among the trace elements associated with coal, Ge is one of the most important in terms of its scope for development and utilization (Goldschmidt 1937). Goldschmidt first discovered the presence of Ge in coal in 1930 and pointed out that $\mathrm{Ge}$ only exists in the primary ash of coal, and relative to high-ash coal, low-ash coal tends to be enriched in Ge (Goldschmidt 1935). The contents of Ge in coal and coal ash are different. In general, the content of Ge in coal is relatively high, and the content of Ge in ash is also high but with the content in ash being several times to dozens of times higher than that of raw coal. In the hydrothermal vents of the mid-ocean ridge in the South Pacific Ocean, Ge and silicon dioxide are positively correlated (Mortlock et al. 1993), and this association is a reflection of the clear pro-silicon properties of Ge.

Generally, it is believed that Ge in coal does not form discrete minerals but is contained within the macromolecular composition of coal. However, the specific organic bonding form of $\mathrm{Ge}$ in coal has been a topic of debate for some time. Many researchers believe that Ge exists in the coal matrix in various chemical forms and at various locations. For example, $\mathrm{Ge}$ is considered to be present on the surface of organic matter present in coal that was formed via a surface redox reaction and surface adsorption (Swaine 1990); in the form of a single organic compound (Seredin 2003); being linked to different functional groups of macromolecules in coal, which are bonded or chelated with humic acid via $\mathrm{Ge}-\mathrm{C}$ bonds (Seredin et al. 2006); and in the form of $\mathrm{O}-\mathrm{Ge}-\mathrm{O}$ and $\mathrm{O}-\mathrm{Ge}-\mathrm{C}$ bonds (Yakushevich et al. 2013). Given that Ge is readily enriched in low rank coals and has well-developed side chains and functional groups with a low degree of order, China's large and oversized Ge-containing coal deposits typically consist of lignite with a relatively low degree of coalification. Germanium present in coal can be adsorbed by both organic matter and the clay minerals. Also, trace amounts of Ge may be detected in sulfide and silicate minerals.
Several researchers have studied the occurrence of Ge in coal, and it has been shown that Ge in combination with organic species are the main forms of Ge in coal (Wang 1999; Yudovich 2003). This is a common consensus based on the results of various tests and chemical analyses (e.g., electrodialysis, chemical extraction, correlation between Ge content and coal particle size grade, specific gravity grade, molecular analyses of coal and rock, and mineral content).

Much research has been undertaken on the modes of aggregation for $\mathrm{Ge}$ and the sources of $\mathrm{Ge}$ in coal. Goldschmidt (1933) believed that the origin of Ge in coal was connected to the uptake of Ge by plants during the plant growth period. Residual enrichment of the more soluble trace elements occurs after leaching from the soil. Thus, after the coal seam was buried, it became enriched in trace elements due to the selective reaction between the $\mathrm{Ge}$ contained in the groundwater and carbon in the coal seam. Published data would seem to indicate that Paleozoic coal may contains less Ge than Mesozoic and Tertiary coal. It may be surmised that the Paleozoic climate was warm and the root length of plants was relatively short, such that only certain elements were absorbed from the soil surface. Moreover, the more luxuriant the plants were, the more serious was the phenomenon of "competition and absorption" between plants, such that the Ge content of the plants was lowered. However, in the Mesozoic, the plants grew tall and were woody, and, accordingly, their roots were deep. Therefore, under such conditions, the elements in question could be absorbed not only from the surface leaching zone but also from the groundwater circulation zone. Therefore, it is inferred that the increase in the content of some trace elements in the Mesozoic reflects an increase in element availability. The above phenomenon is quite consistent with the "contact enrichment" phenomenon of Ge in coal seams (Dai et al. 2007); that is, many trace elements are uniformly distributed in a direction perpendicular to the coal seam, but Ge tends to be concentrated in the top or bottom sections of the coal seam.

Zhuang et al. (2006) proposed that the presence of Ge in coal was related directly to the distribution of sulfides in coal, thus coal with a high sulfide content is generally believed to contain higher amounts of Ge. Hu et al. (2006) found that the coal-bearing strata in the study area (Huinan Coalfield) were sandwiched in the middle volcanic rock series based on an in-depth study of the geological conditions of the wood-based coal producing areas. The coalbearing strata are lacustrine deposits and are characterized by the presence of rich volcanic material. It is surmised that the enrichment of Ge in coal was linked to the surrounding volcanic activity. Experimental and thermodynamic studies (Pokrovski and Schott 1998) demonstrated that the solubility of $\mathrm{GeO}_{2}$ increased with temperature over the range 
$25-250{ }^{\circ} \mathrm{C}$, and maximum solubility was reached for near neutral conditions. It was proposed that only a hot liquid system can transport Ge in large quantities.

At present, the coal-type Ge deposits that have been successfully exploited and utilized in China include the medium and super-large Ge deposits in the Lincang Coalfield of Yunnan Province (Hu and Ye 1996; Hu et al. 2006), and the Ge deposits that coexist with coal in the Wulantuga and Shengli Coalfields of Inner Mongolia (Qing 2001; Qi et al. 2004, 2007a, b). The aforementioned researchers believe that the main chemical forms of $\mathrm{Ge}$ in the two extra-large Ge-containing coal deposits are basically the same, and both chemical forms are organic in nature. The source of supply and the enrichment mode for Ge are basically the same and involve hydrothermal fluids.

The Huainan Coalfield is an important base for coal production, processing, and utilization in eastern China. It is rich in coal resources and has played a huge role in economic activity and construction for the region. The coal-bearing strata in the Huainan Coalfield are the Carboniferous-Permian coal measures. The main coal-bearing strata are the Permian Upper Shihezi Formation, the Lower Shihezi Formation, and the Shanxi Formation. The Carboniferous strata basically do not contain minable coal seams. In view of the inherent coal-bearing formation pattern in the Huainan Coalfield, a large amount of geological prospecting work in the past was mainly concentrated on the Permian coal measures strata which had good coal bearing properties.

According to the available data, research on Ge in the Permian coal in the Huainan Coalfield started in the 1980s. Qian (1988) studied the Ge content of Permian coal using spectrophotometry and determined the average values for $\mathrm{Ge}$ in the different coal seams; the maximum value of Ge was $5.0 \mathrm{mg} / \mathrm{kg}$, the minimum value was $0.2 \mathrm{mg} / \mathrm{kg}$, and the average value was $2.25 \mathrm{mg} / \mathrm{kg}$. Of the results, the average value for Ge in the No. 13 coal seam of the Upper Shihezi Formation was $0.2 \mathrm{mg} / \mathrm{kg}, 2.5 \mathrm{mg} / \mathrm{kg}$ in No. 12; for the Lower Shihezi Formation, the average value in the No. 11 coal seam was $2.5 \mathrm{mg} / \mathrm{kg}, 3.0 \mathrm{mg} / \mathrm{kg}$ in No. $10,2.6 \mathrm{mg} / \mathrm{kg}$ in No. $9,1.6 \mathrm{mg} / \mathrm{kg}$ in No. $8,1.6 \mathrm{mg} / \mathrm{kg}$ in No. $7,0.8 \mathrm{mg} /$ $\mathrm{kg}$ in No. $6,2.5 \mathrm{mg} / \mathrm{kg}$ in No. 5 , and $2.3 \mathrm{mg} / \mathrm{kg}$ in No. 4 coal seam. For comparison purposes, the average Ge content of the Shanxi Formation for the No. 3 coal seam was $2.5 \mathrm{mg} / \mathrm{kg}$, and $5.0 \mathrm{mg} / \mathrm{kg}$ for the No. 1 coal seam.

In the early twenty-first century, Zhao et al. (2002) reported that the range of the Ge content in Permian coal in north China was $1-10 \mathrm{mg} / \mathrm{kg}(n=927)$ with an average value of $5.0 \mathrm{mg} / \mathrm{kg}$ based on a study of the abundance of trace elements in Chinese coal. Tang (2002) reported that the range of the Ge content in Permian coal in Huaibei, Anhui Province was $1.2-4.3 \mathrm{mg} / \mathrm{kg}(n=12)$ with a mean value of $2.42 \mathrm{mg} / \mathrm{kg}$. According to geology reports concerning many (13) large-scale production mines and major exploration areas (7), including the Kouziji exploration area, the Banji exploration area, the LaomiaoYangcun exploration area, the Liu Zhuang deep exploration area, the Daxing exploration area, the LuoyuanLiantangli exploration area and the Panji deep exploration area, the contents of Ge in Permian coal were determined to be $1.0-5.0 \mathrm{mg} / \mathrm{kg}$. Based on the above research data, it is clear that Ge is not enriched in Permian coal in the Huainan Coalfield and belongs to the low Ge coal category.

In recent years, with ongoing application of new theories and methods for coalfield exploration and the continuous development of exploration, the degree of geological control in the Huainan Coalfield has been continuously improved, and the understanding of the accumulation rules for coal-bearing strata with associated mineral resources and the structural control rules for the coalfield have expanded (Tang et al. 2020). Combined with a development strategy of geological prospecting at depth, the coalbearing series of the Taiyuan Formation (Ty) in the in situ system under the Fufeng thrust nappe structural belt in the southern Huainan Coalfield has become an important new prospecting location for the exploration and development of coal-bearing series mineral resources.

In this study, rope coring technology was used to completely core the Ty strata in the in situ system under the Fufeng thrust nappe structural belt via surface drilling in the southern area of the Huainan Coalfield with three Ty coal samples being collected. Inductively-coupled plasma mass spectrometry (ICP-MS) and inductively-coupled plasma atomic emission spectrometry (ICP-AES) were used to determine Ge in the coal samples based on performing two repeat analyses (duplicate analyses) of each coal sample collected. The precision and of the two methods were compared. Then, the Ge content of each coal sample was calculated using the ICP-MS data. The correlations between the Ge content and the geological factors (coal seam thickness and coal quality index) were examined, and the geological conditions and significance of the formation of coal of high $\mathrm{Ge}$ content in the Ty are discussed.

\section{Geological background}

The Huainan Coalfield is located in the southern part of the Huainan-Huaibei plain in Anhui Province, extending into the Chuxian area in the east and near Fuyang city in the west. It is about $180 \mathrm{~km}$ long from east to west, $20-30 \mathrm{~km}$ wide from south to north, and covers an area of about $3654 \mathrm{~km}^{2}$. It is a Carboniferous-Permian coal accumulation basin which developed in the southeast of the north China plate. The Liufu deep fault in the north of the 
coalfield is adjacent to the Bengbu uplift, and the Yingshang-Dingyuan fault in the south is connected to the Hefei Basin through the Fuyang deep fault, the XinchengkouChangfeng fault in the east, and the Zhoukou basin in the west (Fig. 1).

The Huainan Coalfield is affected by the different periods of the structural belts in the surrounding area. It is characterized in terms of having different levels, different orientations, and different structural tectonic deformation characteristics; it exhibits a complex tectonic pattern with multiple structural styles such as extrusion, extension, reversion, slippage and strike-slip. This coalfield, as a whole, presents as an NWW-oriented offset fault-fold structural belt with the Fufeng thrust nappe structural belt in the south, a gravity slip structural belt in the north and a syncline structural belt in the middle.

From bottom to top, the strata in the Huainan Coalfield cover a large area and are developed from the Archean Wuhe Group, the Middle-Neoproterozoic Qingbaikou System, the Sinian System, the Paleozoic Cambrian System, the Middle-Lower Ordovician System, the Carboniferous System, the Permian System and the Lower Triassic System, the Mesozoic Upper Jurassic System, the Cretaceous System, the Cenozoic Paleogene System and the Neogene-Quaternary System. The Late Paleozoic Carboniferous-Permian coal measure strata have a total thickness of $1100 \mathrm{~m}$. By contrast, the Mesozoic and Paleogene strata are scattered and have limited thickness. The Archean-Early Paleozoic ancient strata are exposed in some low mountain areas such as the Bagong Mountains, the Shungeng Mountains, and the Shangyao Mountains. Most other areas with coal measures are buried directly under the Neogene-Quaternary loose strata and have a total thickness of less than $500 \mathrm{~m}$.

The Ty strata in the Huainan Coalfield are integrated or pseudo-integrated in the underlying Benxi Formation strata. The lithology of this group is stable and its thickness alters little, generally being around $90-130 \mathrm{~m}$. The lithology reflects mainly the deposition of a series of platformmultiple barrier island composite systems with regular alternation of clear water and muddy water on the surface of the land and sea, resulting in regular phase cycles in the vertical direction with a clear pattern. The lithology of this group consists mainly of dark gray-gray limestone, sandstone, siltstone, mudstone, carbonaceous shale, and a thin coal seam.

\section{Sampling and experimental}

In view of the fact that the Ty coal measures strata are not in an area known for normal coal exploration, conventional surface exploration drilling is usually carried out in the final hole of the underlying strata of the Shanxi Formation, and coring work for the Ty was not performed. In addition, to ensure the safe mining for the coal seam of the Shanxi Formation No. 1 coal, it is necessary to drain and depressurize the underlying Ty strata; hence this work also does

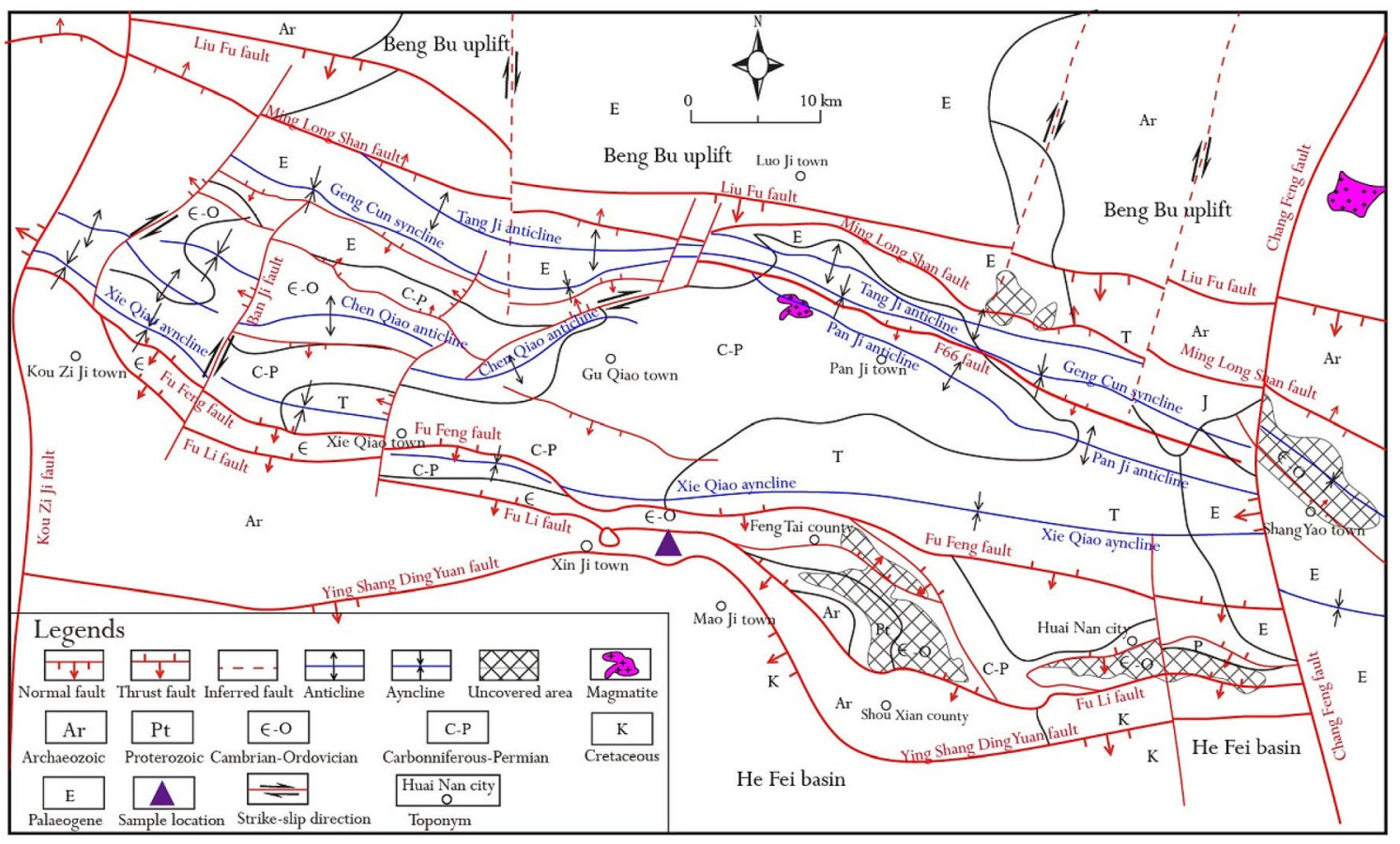

Fig. 1 Structural map of the Huainan Coalfield 
not involve drilling to obtain cores for the Ty strata; therefore, it is very difficult to obtain cores for the Ty in all layers, especially for thin coal seams (which often occur at great depth under the action of high ground stress, and where the sample if taken from depth to the surface explodes to form pulverized coal).

In August 2017, the first oil and gas well HN-1\# was constructed in the Huainan Coalfield. The well is located in the Fufeng thrust nappe structural belt. The well passes through the Archean Gneiss Formation and the Cambrian Formation to the Carboniferous-Permian Formation in the in situ system and ends up in the weathering crust of the Majiagou Formation in the Middle Ordovician. Using rope coring technology, the core samples have been taken from the well for all strata of the Ty, including three thin coal seam samples, which were recorded as Ty1, Ty2 and Ty3, respectively. The sampling information and lithological descriptions for the samples are given in Fig. 2.

Bulk samples were air-dried, sealed in polyethylene bags to prevent contamination and oxidation, and ground through a 200-mesh sieve for chemical analysis. The proximate analyses (volatile matter $\left(V_{\mathrm{daf}}\right)$, moisture $\left(M_{\mathrm{ad}}\right)$, ash yield $\left(A_{\mathrm{d}}\right)$ and fixed carbon $\left(\mathrm{FC}_{\mathrm{d}}\right)$ ) were completed according to ASTM D3172-1989. The ultimate analysis (carbon $\left(\mathrm{C}_{\mathrm{daf}}\right)$, hydrogen $\left(\mathrm{H}_{\mathrm{daf}}\right)$ and nitrogen $\left(\mathrm{N}_{\mathrm{daf}}\right)$ ) was carried out according to ASTM D5373-2008. Total sulfur $\left(\mathrm{S}_{\mathrm{t}, \mathrm{d}}\right)$ was determined using ASTM D2492-2002. Oxygen $\left(\mathrm{O}_{\mathrm{daf}}\right)$ was calculated by the difference method.

\begin{tabular}{|c|c|c|c|c|}
\hline \multicolumn{3}{|c|}{ Chronostratigraphy } & \multirow{2}{*}{ Lithology } & \multirow{2}{*}{$\begin{array}{l}\text { Macro lithologic } \\
\text { description }\end{array}$} \\
\hline System & Series & Formation & & \\
\hline 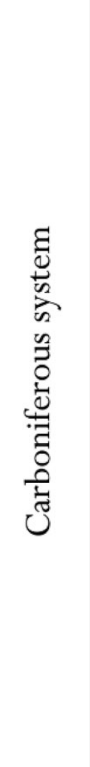 & 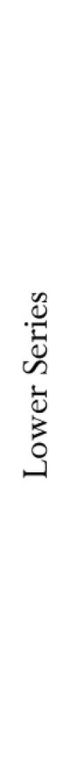 & 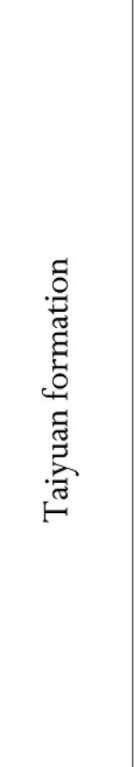 & 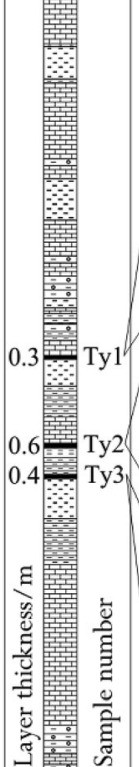 & $\begin{array}{l}\text { The formation thickness ranges } \\
\text { from } 1130 \text { m to } 1236 \mathrm{~m} \text {. } \\
\text { |Black, block-shaped, mixed with } \\
\text { powder, crushed and granular, } \\
\text { mainly bright coal, containing dark } \\
\text { coal, with weak glass luster, } \\
\text { belonging to semi-bright briquette. }\end{array}$ \\
\hline
\end{tabular}

Fig. 2 Histogram of coal-bearing strata of the Taiyuan Formation from $\mathrm{HN}-1 \#$
The collected raw coal samples were dried and crushed to a powder of particle size less than $1 \mathrm{~mm}$. Approximately $8.9 \mathrm{~g}$ of powdered coal was added to a polyethylene sample container; $2.7 \mathrm{~mL}$ of hardening agent was mixed with $28 \mathrm{~g}$ of resin to prepare a binder; a small amount of binder was then added to each coal sample and after rapid stirring and mixing, the binder was fully stirred, the coal particles and the resin binder were fully mixed, and then the mixture was placed in an oven at $50{ }^{\circ} \mathrm{C}$ for approximately 2 to $3 \mathrm{~h}$. On completion of the reaction, the polished sheet was rubbed, in turn, with $0.05 \mu \mathrm{m}$ polishing paper (rough polishing) and aluminum mud (fine polishing), respectively, in a slitting machine. The final optical sheet was observed under an optical microscope with an amplification factor of $\times 500$. The main microscopic components were identified and classified by oil-immersed reflected monopolarized light based on photography and counting at several points.

To determine the ash content of samples, $100 \mathrm{~g}$ of pulverized coal samples were heated at $550{ }^{\circ} \mathrm{C}$ to remove organic matter and weighed to constant weight before determination of the major element oxides in the ash. The results were recalculated based of the weight of the coal sample taken. The oxides of major elements in the powder sample, including $\mathrm{SiO}_{2}, \mathrm{Al}_{2} \mathrm{O}_{3}, \mathrm{Fe}_{2} \mathrm{O}_{3}, \mathrm{MnO}, \mathrm{TiO}_{2}, \mathrm{CaO}$, $\mathrm{K}_{2} \mathrm{O}, \mathrm{SO}_{3}, \mathrm{P}_{2} \mathrm{O}_{5}, \mathrm{Na}_{2} \mathrm{O}$, and $\mathrm{MgO}$, were determined by $\mathrm{X}$-ray fluorescence spectrometry (XRF, model XRF-1800).

The vitrinite reflectance values of the coal samples were measured using the CRAIC CoalPro III vitrinite reflectance instrument. The 50/0.85 resolution was used as an oil immersion object. To obtain the average vitrinite reflectance of coal samples at different temperatures, at least 15 vitrinite particles in each sample were selected for reflectance measurements.

About $100 \mathrm{~g}$ of split samples were manually crushed in a quartz mortar using a manual grinding rod. Then, the portion of the homogenized sample which passed through the 200-mesh sieve was subsampled in quadruplicate and dried in an oven $\left(25^{\circ} \mathrm{C}\right)$ for $12 \mathrm{~h}$. Using an acid mixture $\left(\mathrm{HNO}_{3}: \mathrm{HCl}: \mathrm{HF}=3: 1: 1\right)$, an 0.2 to $0.4 \mathrm{~g}$ aliquot of powdered sample was subjected to microwave-assisted digestion (Multiwave 3000, Anton Paar). The acids used for digestion were high purity $\mathrm{HNO}_{3}$ and $\mathrm{HCl}$ (double distilled) and ultra-pure concentrated HF.

To determine the Ge content of the coal samples, replicate (in duplicate) analyses of each coal sample digest were performed using ICP-MS and ICP-AES. The ICPAES instrument, an Optima 7300 DV (Perkin-Elmer Cooperation), afforded a resolution of $0.003 \mathrm{~nm}$, detection limits of $0.2-4 \mathrm{ng} / \mathrm{mL}$ and a coefficient of variation $(\mathrm{CV})$ of $<0.5 \%$ for measurement of a $1 \mathrm{mg} / \mathrm{mL}$ mixed multi-element solution. The ICP-MS instrument was an X Series 2 model(Thermo Fisher Scientific) and afforded elemental determinations at unit mass resolution over the mass range 
2-255. The limits of detection and CV value of ICP-MS for analysis $1 \mathrm{mg} / \mathrm{L}$ standard solution is $0.1 \mathrm{mg} / \mathrm{g}$.

The ICP-MS and ICP-AES instruments were calibrated with the certified reference material NIST-1632b (coal) before determination of the Ge contents in the coal samples. This CRM has a certified value for Ge of $5.20 \mathrm{mg} / \mathrm{g}$. There was good consistency between the measured values (ICP-AES and ICP-MS) and the certified value, the deviations being within $\pm 10 \%$.

The carbon isotopic compositions of the coal samples were determined by elemental analysis-stable isotope mass spectrometry (SIMS model MAT253; Thermo Fisher Company). The main instrumental parameters were: mass range 1-150 Dalton, acceleration voltage $10 \mathrm{~V}$, resolution $m / \Delta m=200$ (10\% valley), and amplifier output range 0$50 \mathrm{~V}$. The detailed procedure was as follows: each portion of the this study coalsample was sifted and divided into a series of partial samples. After grinding, the samples were screened using a 100-mesh sieve. Then $5 \mathrm{~g}$ of sample was removed, and reacted with excess $\mathrm{HCl}(4 \mathrm{~mol} / \mathrm{L})$ at room temperature for $24 \mathrm{~h}$. With deionized water (adjust to (neutral $\mathrm{pH}$ ) with deionized water), the samples were dried at $60{ }^{\circ} \mathrm{C}$ in an oven, weighed to constant weight, and ground into a powder, before passage through a 60-mesh sieve. About $10 \mathrm{mg}$ of powdered sample was weighed accurately. The powdered sample was placed into the sample loading vial, which was then inserted into the automatic sample loading tray. After that, the sample combustion, injection of reference gas, mass spectrometry analysis and data processing were performed by the onboard computer. The $\delta^{13} \mathrm{C}_{\text {org }}$ values for the coal samples were calculated using Eq. (1).

$\delta^{13} \mathrm{C}_{\mathrm{org}}(\%)=\left[\frac{R\left({ }^{13} \mathrm{C} /{ }^{12} \mathrm{C}_{\mathrm{org}}\right)}{R\left({ }^{13} \mathrm{C} /{ }^{12} \mathrm{C}_{\mathrm{VPDB}}\right)} I\right] \times 1000$

In Eq. (1), $R\left({ }^{13} \mathrm{C} /{ }^{12} \mathrm{C}_{\mathrm{VPDB}}\right)$ is the ratio of the carbon isotope abundance of the international standard VPDB (IAEA, Vienna). The analysis precision for measurement of $\delta^{13} \mathrm{C}_{\text {org }}$ was $0.2 \%$. The analytical values for the organic carbon isotopes of the coal samples are listed in Table 1.

A NanoScope atomic force microscope (AFM) (Digital Company, model SPA-300HV, Chiba, Japan) was used to provide insights into the morphological characteristics of the coal samples. The maximum scanning range was $30 \mu \mathrm{m} \times 30 \mu \mathrm{m} \times 2 \mu \mathrm{m}$. The automatic scanning surface groove setting was $1800 / \mathrm{mm}$, which can afford good resolution of the topography of the coal surface. Details on sample preparation and the experimental conditions have been reported in a previous study ( $\mathrm{Wu}$ et al. 2014). The scanning images at different temperatures were interpreted using NanoScope Analysis software (ver. 1.40).

In an attempt to analyze comprehensively the oxidizing and reducing environments that existed during the coal formation process, the fluorescence of the organic matter in the coal seam roof and floor (such as mudstone and bioclastic limestone) was recorded. The MT/T 595-1996 standard method was used as the test method, and a Nikon fluorescence microscope (model LV100N POL) was used as the test instrument. These studies were undertaken at room temperature.

The experimental flow chart for the study is given in Fig. 3.

\section{Results and discussion}

\subsection{Basic properties of coal from the Taiyuan Formation}

The analytical results for the basic properties of the three coal samples from the Ty are shown in Table 1. The data show that the analysis indexes for the three samples are slightly different. According to the classification table for the coal rank index changes during coalification as proposed by Stach (1982), based on the $V_{\text {daf }}$ and $C_{\text {daf }}$ values, the coal rank for the Ty corresponds to that between a subbituminous coal A and a high volatility bituminous coal A.

The sulfur (S) content of a coal seam depends mainly on the formation conditions of the coal and the strata of the roof. The change in S content reflects the change in the deposition conditions during peat formation. The Ty coal has a high $\mathrm{S}$ content (Table 1), and the $\mathrm{S}_{\mathrm{t}, \mathrm{d}}$ values are generally between $3 \%$ and $4 \%$, which is basically 5-6 times that of Permian coal (S content $0.57 \%-0.68 \%$; Hu

Table 1 Results for the basic properties of the Taiyuan Formation coal samples

\begin{tabular}{|c|c|c|c|c|c|c|c|c|c|c|c|c|c|}
\hline \multirow[t]{2}{*}{ Sample } & \multicolumn{4}{|c|}{ Proximate analysis (\%) } & \multicolumn{5}{|c|}{ Ultimate analysis (\%) } & \multicolumn{3}{|c|}{ Macerals (\%) } & \multirow{2}{*}{$\begin{array}{l}\text { Vitrinite reflectance }(\%) \\
R_{\mathrm{O}}\end{array}$} \\
\hline & $V_{\mathrm{daf}}$ & $M_{\mathrm{ad}}$ & $A_{\mathrm{d}}$ & $\mathrm{FC}_{\mathrm{d}}$ & $\mathrm{C}_{\mathrm{daf}}$ & $\mathrm{H}_{\mathrm{daf}}$ & $\mathrm{O}_{\mathrm{daf}}$ & $\mathrm{N}_{\mathrm{daf}}$ & $S_{t, d}$ & $V$ & $I$ & E & \\
\hline Ту1 & 43.99 & 0.80 & 11.01 & 49.85 & 81.77 & 5.28 & 7.78 & 1.45 & 3.31 & 87.5 & 9.8 & 2.7 & 1.16 \\
\hline Ту2 & 45.60 & 0.91 & 15.50 & 50.93 & 81.48 & 5.55 & 7.36 & 1.36 & 3.59 & 80.8 & 12.1 & 7.1 & 1.17 \\
\hline Ту 3 & 44.49 & 0.96 & 11.58 & 49.08 & 82.67 & 5.58 & 5.58 & 1.37 & 4.24 & 82.2 & 11.2 & 6.7 & 1.18 \\
\hline
\end{tabular}

$V$ Vitrinite, $I$ Inertinite, $E$ Exinite, daf dry ash-free basis, ad air dried basis, $d$ dry basis 


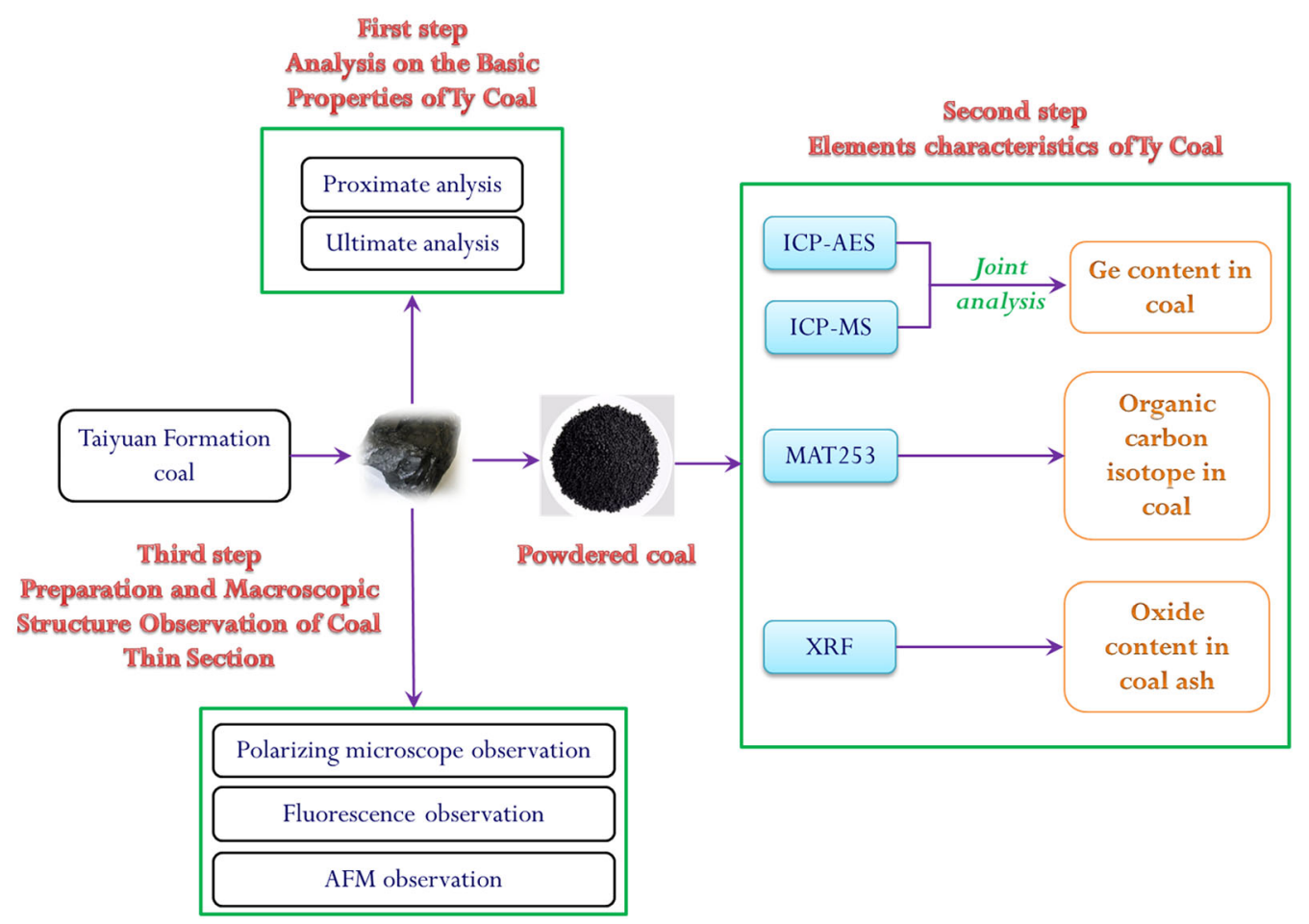

Fig. 3 Experimental flow chart for characterization studies of the Taiyuan Formation coal samples

et al. (2018)) in the Huainan Coalfield. Clearly, the Ty coal has had a close association with seawater for a long time during the peat formation process, thus its $\mathrm{S}$ content is relatively high. The vitrinite reflectance values of the coal samples were between $1.16 \%$ and $1.18 \%$ with an average value of $1.17 \%$, which corresponds to a low metamorphic bituminous coal. In addition, compositional analysis of the coal ash can also be used to identify the coal phase. As can be seen from Table 2, the $\mathrm{SO}_{3}$ content of the Ty coal is generally above $4.5 \%$ with a maximum value of $4.98 \%$. Huang et al. (2001) studied in a systematic manner the ash composition of different coals in the Huainan Coalfield. The results showed that the average value of $\mathrm{SO}_{3}$ in Permian coals was $2.09 \%$ and the maximum value of $3.90 \%$ was found in the No. 1 coal seam. From this it can be deduced that the Ty coal has been strongly affected by seawater, while the other coal seams, in general, have had less of an association with seawater. In the area of the lower delta plain where there are tributaries, some coal seams (e.g., No. 1 coal seam) may also have a slightly higher S content due to an spasmodic ingress of seawater.

The change in the $k$ value of the coal ash composition index also clearly reflects the change of the geochemical environment and the paleogeographic environment of the swampy peat. It is generally believed that the ash composition of coal which was formed in the high-level peat swamps with a low phreatic surface and, which relied mainly on atmospheric precipitation for the supply of water, consisted mostly of $\mathrm{SiO}_{2}$ and $\mathrm{Al}_{2} \mathrm{O}_{3}$, i.e., the $k$ value is high, On the one hand, this reflects the fact that $\mathrm{SiO}_{2}$ and $\mathrm{Al}_{2} \mathrm{O}_{3}$ originated mainly from airborne dust; on the other hand, the supply of $\mathrm{SiO}_{2}$ and $\mathrm{Al}_{2} \mathrm{O}_{3}$ indicates that these components were controlled by the supply of continental debris.

It is known that the $\mathrm{Fe}_{2} \mathrm{O}_{3}+\mathrm{CaO}+\mathrm{MgO}$ (FCM) content of coals is relatively high in low-level peat

Table 2 Elemental composition of the ash of the Taiyuan Formation coal

\begin{tabular}{|c|c|c|c|c|c|c|c|c|c|c|c|c|c|c|}
\hline \multirow[b]{2}{*}{ Sample } & \multicolumn{13}{|c|}{ Element composition (\%) } & \multirow[b]{2}{*}{$k$} \\
\hline & $\mathrm{SiO}_{2}$ & $\mathrm{Al}_{2} \mathrm{O}_{3}$ & $\mathrm{Fe}_{2} \mathrm{O}_{3}$ & $\mathrm{MnO}$ & $\mathrm{TiO}_{2}$ & $\mathrm{CaO}$ & $\mathrm{K}_{2} \mathrm{O}$ & $\mathrm{SO}_{3}$ & $\mathrm{P}_{2} \mathrm{O}_{5}$ & $\mathrm{Na}_{2} \mathrm{O}$ & $\mathrm{MgO}$ & FCM & SA & \\
\hline Ту1 & 51.92 & 7.63 & 26.52 & 2.40 & 0.23 & 4.73 & 0.26 & 4.92 & 0.28 & 0.07 & 0.56 & 31.81 & 59.55 & 1.87 \\
\hline Ту2 & 53.73 & 8.18 & 24.3 & 2.38 & 0.29 & 4.14 & 0.58 & 4.98 & 0.22 & 0.24 & 0.46 & 28.90 & 61.91 & 2.14 \\
\hline Ту3 & 53.82 & 8.27 & 24.79 & 2.31 & 0.22 & 4.24 & 0.51 & 4.60 & 0.30 & 0.14 & 0.52 & 29.55 & 62.09 & 2.10 \\
\hline
\end{tabular}

$\mathrm{FCM}=\mathrm{Fe}_{2} \mathrm{O}_{3}+\mathrm{CaO}+\mathrm{MgO} ; \mathrm{SA}=\mathrm{SiO}_{2}+\mathrm{Al}_{2} \mathrm{O}_{3} ; \mathrm{k}=\left(\mathrm{SiO}_{2}+\mathrm{Al}_{2} \mathrm{O}_{3}\right) /\left(\mathrm{Fe}_{2} \mathrm{O}_{3}+\mathrm{CaO}+\mathrm{MgO}\right)$ 
swamps, which may be caused by the presence of excess surface water and groundwater. The coastal brackish waters and saline peat swamps, which are strongly affected by sea water, contain abundant electrolytes, so on encountering such swamps, the dynamic potential of the $\mathrm{Fe}(\mathrm{OH})_{3}$ colloids would be close to 0 , and the diffusion layer would tend to disappear, thus precipitate. As for $\mathrm{Ca}^{2+}$ and $\mathrm{Mg}^{2+}$, these ions are enriched in seawater, so the $k$ value is naturally low. The $k$ values for the Ty coal samples found in this work are approximately 2.0 (Table 2) with a minimum value of 1.87 (Ty1). The $k$ values of Permian coal are between 4.87 and 9.34, with an average value of 6.89 (Huang et al. (2001)). Thus, it can be inferred that the Ty coal was formed in a strongly reducing environment (Table 3).

The microscopic coal petrology and the statistical analysis of the macerals of the three coal samples (Table 1 and Fig. 4) indicate that the content of exinite is not high, is generally between $3 \%$ and $7 \%$ with an average value below 7\%; however, the content of exinite in Ty1 is less than that of Ty 2 and Ty3. The macerals of exinite are mainly resinite and cutinite. The content of inertinite is about $10 \%$, with little change between samples. The macerals of inertinite are mainly fusinite and semifusinite. The macerals in the three Taiyuan coals are mainly vitrinite, and vitrinite is characterized by the presence of telinite. The submicroscopic composition is mainly collodetrinite and this contains a certain amount of telocollinite, which emits fluorescence. Some of the vitrinite shows a clear transition from collodetrinite to asphaltene. In addition, a small amount of agglomerated pyrite is found in the Ty coal (Fig. 4).

\subsection{Analysis of the coal forming environment}

The degree of enrichment of Ge in coal is closely related to the environment in which the coal had formed. According to previous research, the enrichment of $\mathrm{Ge}$ in coal is related to the content of organic matter and to the reducing environment existing at the time of the coal-forming process.
As discussed earlier, a small amount of pyrite particles was found in the coal seam of the Ty, while the contents of pyrite and algae were relatively high in the roof and floor of the coal seam. With reference to the fluorescence experiment concerning the presence of organic matter and the mineral components in the roof and floor of the Ty- 1 coal seam, for the bioclastic limestone of the Ty- 1 roof, there was a large amount of asphalt in the fissures and pores of the carbonate rocks, and the asphaltene bodies and common algae bodies were well developed (Fig. 5a). The algae bodies, which are hollow and emit yellow fluorescence and are common organic inclusions in bioclastic and pyrite, were well-developed (Fig. 5b); also in the floor of the coal seam where silty mudstone was present, the organic matter was composed mainly of microscopic components of vitrinite, a small amount of inert material, and a mineral asphalt matrix, which emitted weak fluorescence (Fig. 6a) and contained shell debris and pyrite (Fig. 6b). The above analysis shows that the peat bog existing during the formation of the Ty coal seam was strongly affected by sea water, and the degree of mineralization of the coal seam was relatively high; these conditions would have provided a favorable setting for establishing a reducing environment at the coastal site and for enrichment of Ge in the coal.

In the present study, two Ty coal samples (Ty1 and Ty3) were analyzed by AFM and Nanoscope Analysis software (ver. 1.40) was used for image interpretation. The purpose of using AFM was to study the degree of development of micro-nano pores (pore size, pore morphology, specific surface area, etc.) in the coal samples. The surface structure of the samples consisted of three main parts, that is, surface minerals, the coal matrix and the nanoscale pore structure. As can be seen from Fig. 7a, the nanoscale pores on the surface of the Ty1 sample are mainly round and oval in shape, and the connectivity between pores is well-defined. These pores can mainly be classified as belonging to the thermogenic pores' category. Germanium can occur in organic matter which resides between mineral particles and exists mainly as humic acid-Ge complexes and organo-Ge compounds. The surface morphology of the Ty3 sample

Table 3 Measured and calculated values for Ge in Taiyuan Formation coal samples

\begin{tabular}{|c|c|c|c|c|c|c|c|c|}
\hline \multirow[t]{2}{*}{ Sample } & \multicolumn{3}{|c|}{ ICP-MS } & \multicolumn{3}{|c|}{ ICP-AES } & \multirow{2}{*}{$\begin{array}{l}\text { Results of precision } \\
\text { comparison test }\end{array}$} & \multirow[t]{2}{*}{$\mathrm{CV}(\mathrm{mg} / \mathrm{kg})$} \\
\hline & $\mathrm{MV}(\mathrm{n}$ & & $w_{i}$ & $\mathrm{MV}(\mathrm{n}$ & & $w_{i}$ & & \\
\hline Ty1 & 22.04 & 22.06 & 0.02 & 21.14 & 21.18 & 0.04 & ICP-MS & 22.05 \\
\hline Ту2 & 4.96 & 4.98 & 0.02 & 4.92 & 4.96 & 0.04 & ICP-MS & 4.97 \\
\hline Ту3 & 20.11 & 20.14 & 0.03 & 19.89 & 19.94 & 0.05 & ICP-MS & 20.13 \\
\hline
\end{tabular}

$M V$ measured value, $w_{i}$ : difference between measured values, $C V$ calculated value = arithmetic mean value after precision comparison 

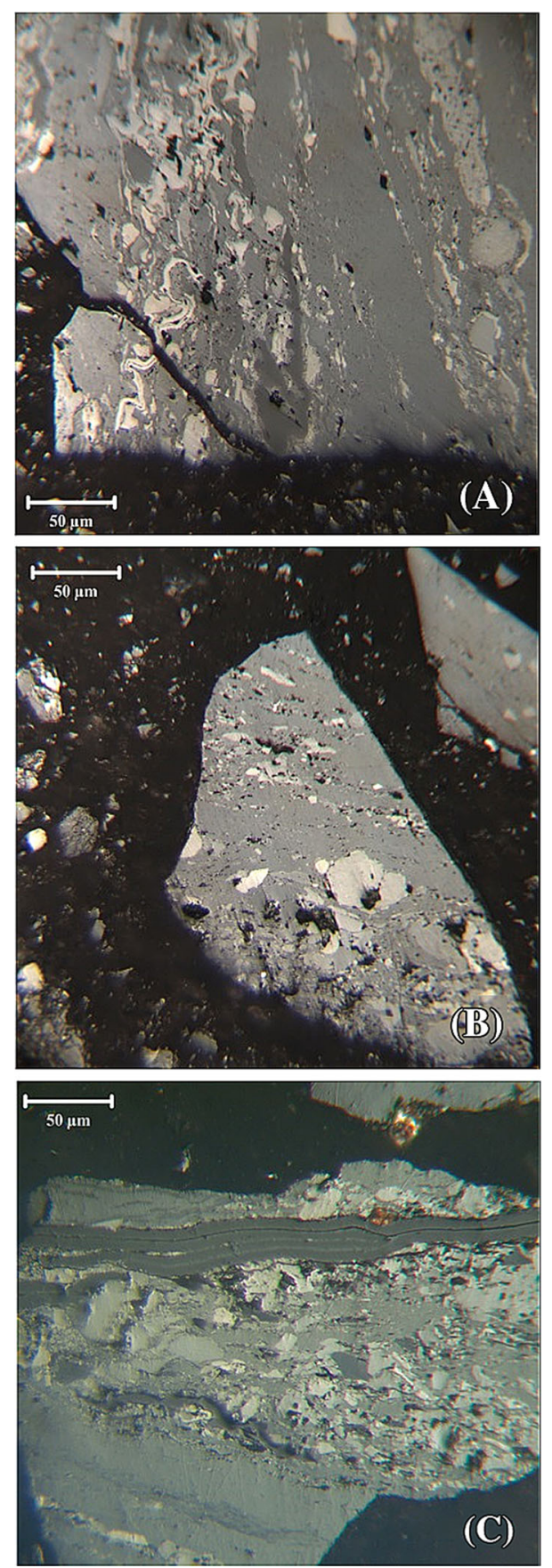

Fig. 4 Macerals types in Taiyuan Formation coal. a The left half is collodetrinite, which serves as a matrix for cementation of fusinite, semifusinite and cutinite. The long band in the middle is telocollinite. b Collodetrinite, on which a mixture of fusinite, inertinite and macrinite are cemented. $\mathbf{c}$ The long band in the upper part is sporinite; collodetrinite, cemented with semifusinite, fusinite and resinite, is in the middle and where a small amount of pyrite development may be observed

(scale $2 \mu \mathrm{m}$ ) is shown in Fig. 7b, and where it can be seen that a few endogenous fissures are developed; also nanoscale pores on the surfaces of the coal organic matter and minerals are well developed, and these pores facilitate the adsorption of $\mathrm{Ge}$ on organic matter, clay minerals and limonite. Based on our findings, it is speculated that the relatively open pore spaces found in the Ty 2 and Ty 3 coal samples facilitates enrichment and aggregation of Ge.

Carbon isotope analysis of coal is of great significance for studying the primitive plant types, the accumulation environment, and the degree of biochemical activity experienced by the peat. As can be seen from Table 2, the organic carbon isotope values for the Ty coal samples ranged from $-24.1 \%$ to $-23.8 \%$, with an average value of $-24.0 \%$, which is equivalent to the carbon isotope value of terrestrial plants (average of $-24.0 \%$ ). The coal seam of the Ty was formed in a brackish or saline water environment which was affected by seawater and the coal seam contained low-grade algae fossils as evidenced by the sample fluorescence (see Figs. 5, 6). Unstructured humic bands and the coal matrix components were observed under the polarizing microscope (see Fig. 4a). Collectively, these findings indicate that Ty coal experienced strong biochemical activity and exchange at the formation stage, processes that would favor lighter $\delta^{13} \mathrm{C}$ values.

\subsection{The Ge content of the Taiyuan formation coal}

In this study, two different analytical methods, ICP-MS and ICP-AES, were used to determine (in duplicate) the Ge content of the coal samples of the Ty with each sample digest being measured repeatedly $(n=3)$ to obtain highprecision values for Ge. The analytical results are presented in Table 2. In terms of accuracy, the analytical values for $\mathrm{Ge}$ in the three samples by the two analytical techniques were quite similar, but for an assessment of the precision of the two methods, the results for the paired comparison test can be assessed. The specific steps are as follows:

If method A (e.g., ICP-MS) and method B (e.g., ICPAES) are used to perform duplicate measurements on each of the M samples (in this case 3 samples), respectively, the respective variances can be calculated according to the following formulae:

$S_{A}^{2}=\frac{\sum_{i=1}^{M} w_{A_{i}}^{2}}{2 M}$

$S_{B}^{2}=\frac{\sum_{i=1}^{M} w_{B_{i}}^{2}}{2 M}$

where $w_{i}$ is the difference between the results of two repeat determinations.

After that, the F-test is carried out: 

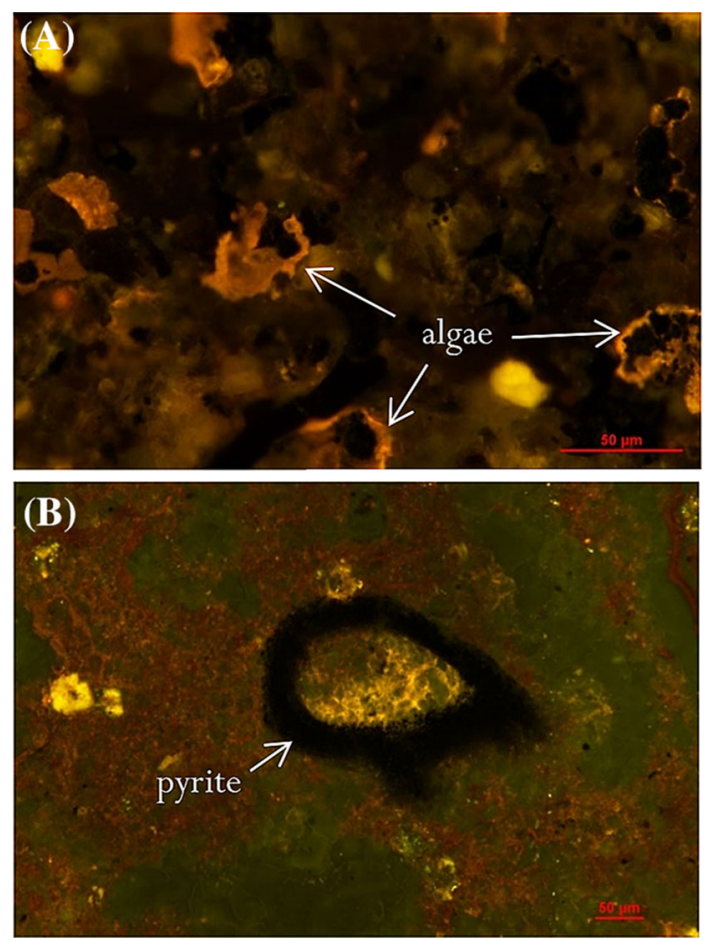

Fig. 5 Fluorescence of limestone in the roof of the Ty1 coal seam: pyrite developed within or on the surface of asphaltene or algae (a); bioclastic was metasomatized and made fluorescent by the presence of pyrite (b)

$F=\frac{s_{A}^{2}}{s_{B}^{2}}$ or $F=\frac{s_{B}^{2}}{s_{A}^{2}}$ (more variance as a numerator)

For a given level of significance $\alpha$ and the number of degrees of freedom, the critical value $\left(F_{\alpha, f_{1}, f_{2}}\right)$ is obtained from the $F$ table. If $F \leq F_{\alpha, f_{1}, f_{2}}$, there is no significant difference in precision between the two methods. If $F>F_{\alpha, f_{1}, f_{2}}$, the precision of the two methods is significantly different, and the precision of the method on the denominator is significantly better than that on the numerator. The significance level for making this judgment is $2 \alpha$.

In this study, the precisions of ICP-MS and ICP-AES were compared by performing the above tests. From Table 2, the variances of the two methods can be calculated as:

$S_{I C P-M S}^{2}=\frac{\sum_{i=1}^{3}\left(0.02^{2}+0.02^{2}+0.03^{2}\right)}{2 \times 3}=0.000283$

$S_{I C P-A E S}^{2}=\frac{\sum_{i=1}^{3}\left(0.04^{2}+0.04^{2}+0.05^{2}\right)}{2 \times 3}=0.000950$
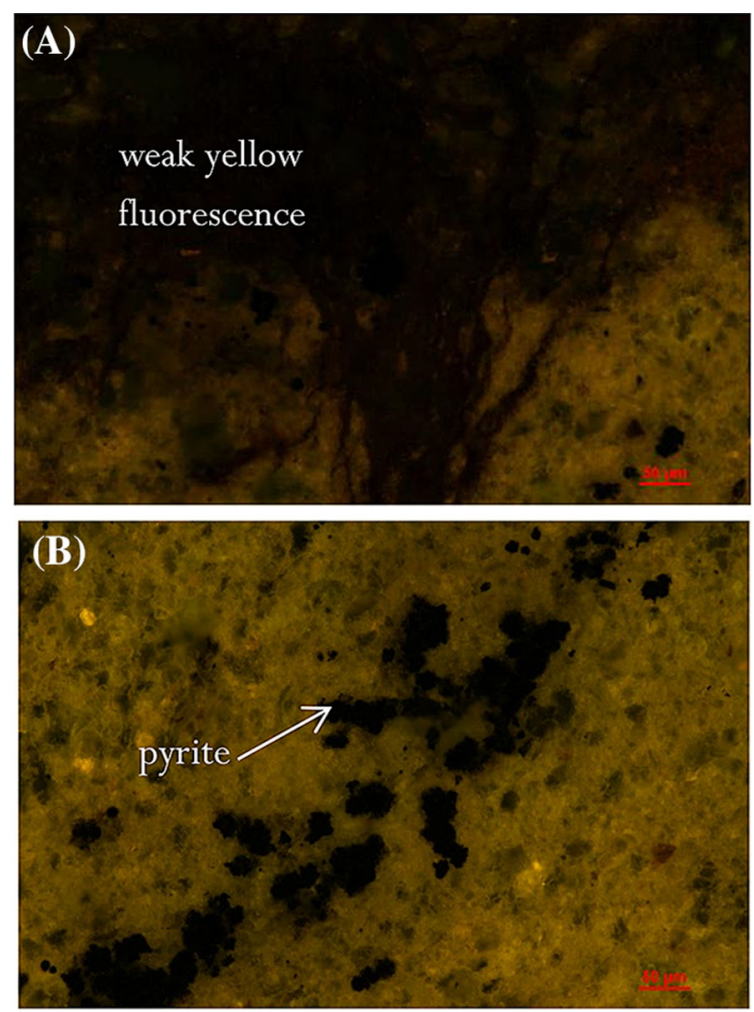

Fig. 6 Fluorescence of silty mudstone in the floor of the Ty1 coal seam (weak yellow fluorescence of mineral asphalt matrix) (a), containing shell debris, and more pyrite in matrix (b)

$F=\frac{S_{I C P-A E S}^{2}}{S_{I C P-M S}^{2}}=\frac{0.000950}{0.000283}=3.3529$

According to the $F$ table, $F_{0.05,9,9}=3.18$. Given that $F=3.3529>3.18$, the precision of the two methods is significantly different. The precision of ICP-MS is significantly better than that of ICP-AES (the significance level is 0.10). On the basis of the above test, the analytical values for $\mathrm{Ge}$ in each coal sample are the average values for duplicate analyses by the ICP-MS method (Table 2), namely, Ty1: $22.05 \mathrm{mg} / \mathrm{kg}$, Ty2: $4.97 \mathrm{mg} / \mathrm{kg}$ and Ty3: $20.13 \mathrm{mg} / \mathrm{kg}$.

According to the classification system for Ge in coal (MT/T 967-2005), samples Ty1 and Ty3 belong to a high Ge coal category while sample Ty2 belongs to a low Ge coal category. The thicknesses of the coal seam corresponding to the three samples are $0.3 \mathrm{~m}$ (Ty1), $0.6 \mathrm{~m}$ (Ty2) and $0.4 \mathrm{~m}$ (Ty3), respectively. According to the reserve weighting method, the weighted average value of the $\mathrm{Ge}$ content of the Ty coal is $13.57 \mathrm{mg} / \mathrm{kg}$, which is much higher than the arithmetic mean $(2.25 \mathrm{mg} / \mathrm{kg})$ and the maximum value $(5.0 \mathrm{mg} / \mathrm{kg})$ for the Ge content in the Permian coal of the Huainan Coalfield. These data indicate 


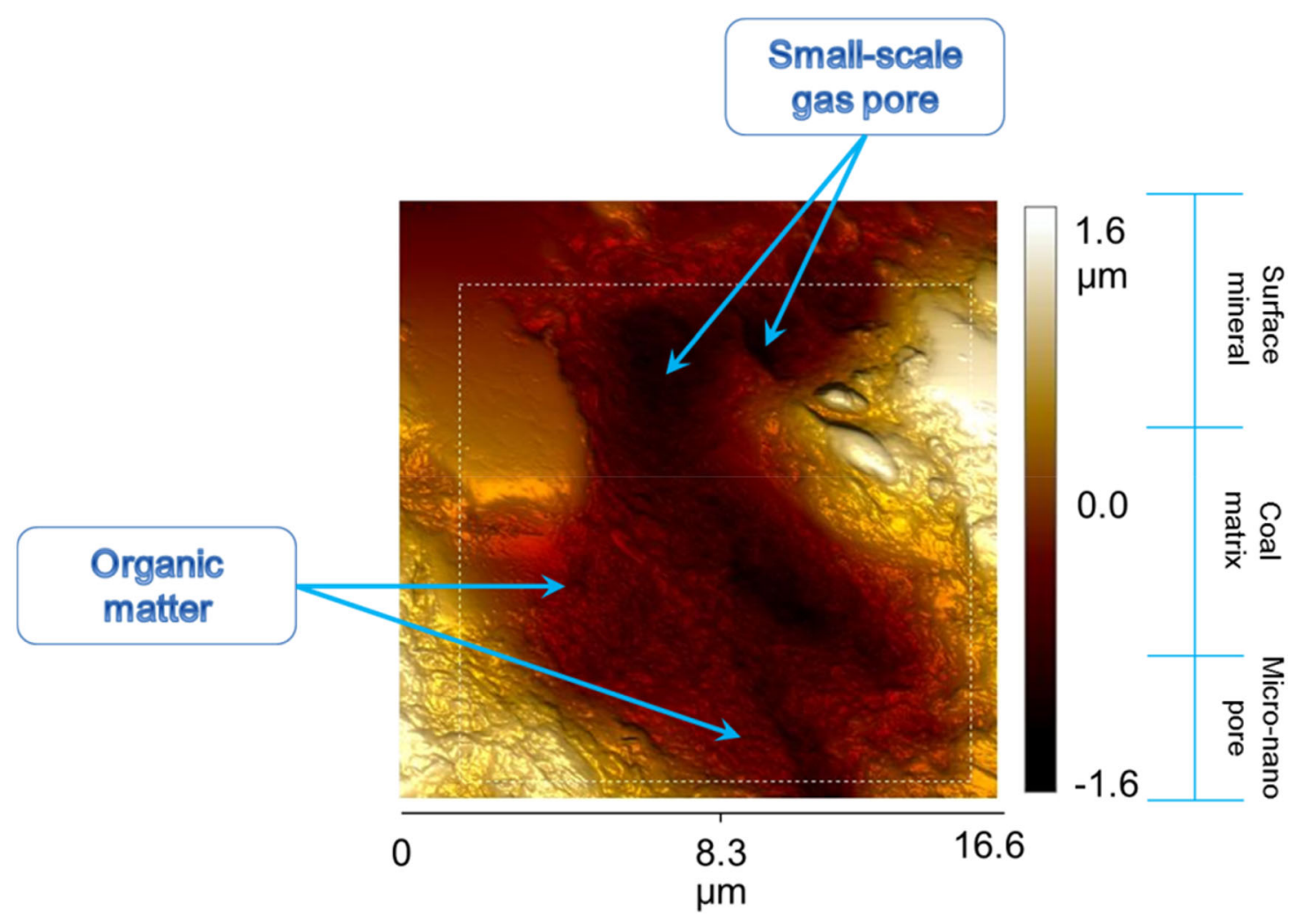

Ty1 sample (a)

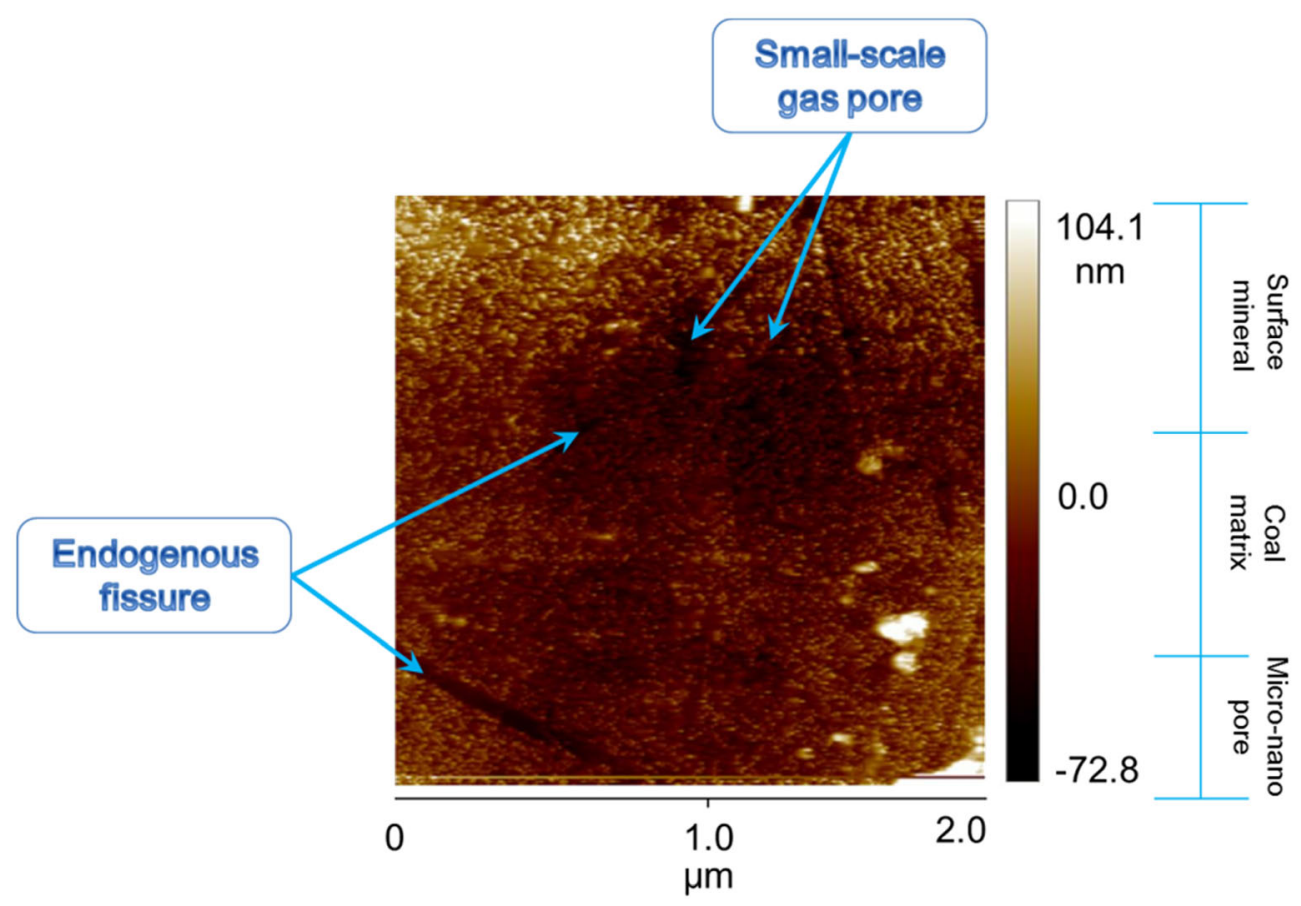

Ty3 sample (b)

Fig. 7 Atomic force microscopy of Ty1 and Ty3 coal samples 
that Ty coal has exploration potential with respect to the associated Ge resources, especially the thinner coal seams.

\subsection{Relationship between Ge enrichment and $V_{\text {daf }}$ and $A_{\text {ad }}$}

To better understand the relationship between the $\mathrm{Ge}$ content and coal quality in the Ty, regression analysis was carried out on the Ge content values and the $V_{\text {daf }}$ and $A_{\text {ad }}$ values (Fig. 8). It can be seen from Fig. 8 that there is significant negative correlation between the Ge content of coal and the $V_{\text {daf }}$ and $A_{\text {ad }}$ values.

Previous studies have shown that, in general, the Ge content of coal is inversely proportional to the ash yield and directly proportional to the volatile components. On this basis, the predominant forms of Ge in coal are mainly organic in nature and tend to be concentrated in the lignite of low rank coal. Low-rank lignite generally contains more volatile matter and the content of organic matter is relatively high, a situation which is conducive to chemical reactions occurring between the Ge and organic matter in coal to produce humic acid-Ge complexes and Ge-containing organic compounds. This conclusion has also been reached by other researchers. For example, the extra-large Ge deposit in Lincang, Yunnan Province is a Ge-U coal composite deposit with Ge being the primary constituent. The coal in the deposit belongs to lignite of low rank. Dai et al. (2015) undertook a comprehensive study on the Lincang extra-large coal-bearing $\mathrm{Ge}$ deposit in Yunnan Province using various test methods and demonstrated the existence of various chemical forms of Ge; specifically, the $\mathrm{Ge}$ in the deposit formed strong chemical bonds with organic matter and mainly consisted of humic acid-Ge complexes and organic compounds of Ge. Dai et al.
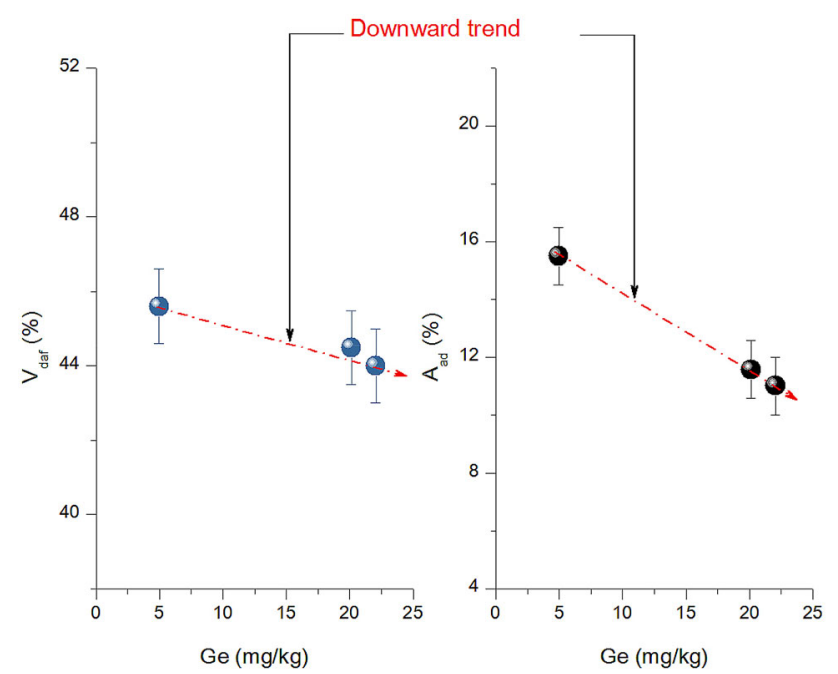

Fig. 8 Correlations between $\mathrm{Ge}$ and $V_{\mathrm{daf}}$ and $A_{\mathrm{ad}}$ in Taiyuan Formation Coal (2012a, b) studied systematically the chemical forms of Ge in the oversize Ge-bearing coal deposits in the Shengli Coalfield, Inner Mongolia. The results confirmed that Ge in the Ge deposit consisted mainly of humic acid complexes formed by reaction of organic matter with $\mathrm{Ge}$-containing organic compounds. In the present study, however, the $V_{\text {daf }}$ value for Ty2 was slightly higher (by $1.11 \%$ ) than that for Ty3, but the Ge content was much lower (by $15.16 \mathrm{mg} / \mathrm{kg}$ ). From inspection of the histogram for the HN-1\# borehole (Fig. 2), it can be seen that the interval between the two coal seams is relatively small, which indicates that the two seams may be formed in a parallel coal-forming environment (coal-forming plants, $\mathrm{pH}$ conditions of peat swamps and Ge supply capacity of groundwater). Under suitable $\mathrm{pH}$ conditions $(7<\mathrm{pH}<8.5)$, the $\mathrm{Ge}$ present in environmental media can be estimated as the combination of Ge in plants and that extracted from the groundwater, ultimately forming a humic acid gelatum of Ge. This process is similar to the capture of Ge by plants in the coal-forming process. An analogous process should apply for Ty2 and Ty3. The further enrichment of Ge to form Ge-containing coal requires condensation of Ge-containing humic acid gelatum during the coal formation process, which would determine the degree of enrichment of $\mathrm{Ge}$ in the coal. Therefore, it is speculated that the low Ge content in the Ty2 sample is mainly due to the fact that the Ge-containing organic compounds do not undergo deep condensation during gelatification.

\section{Conclusions}

The enrichment characteristics for Ge in the Ty coal of the Huainan Coalfield and the correlation of Ge content with the coal quality indexes have been reported for the first time. The main findings and conclusions are as follows:

(1) The rank of Ty coal is relatively low and the $S_{t, d}$ content is extremely high. The ash index $(k)$ indicates that Ty coal was formed in a strongly reducing environment. The macerals in the coal are mainly vitrinite, while the content of collodetrinite in the submacerals is relatively high.

(2) By comparing the analytical values for the $\mathrm{Ge}$ content of the coal samples using two independent methods (ICP-MS and ICP-AES), the Ge contents for the three coal samples, Ty1, Ty2 and Ty3, were deemed to be $22.05,4.97$ and $20.13 \mathrm{mg} / \mathrm{kg}$, respectively. The weighted reserve value for the Ge content of Ty coal was $13.57 \mathrm{mg} / \mathrm{kg}$. Overall, the results indicated that the Ge content in the thin coal seam was relatively enriched compared to Permian coal in the Huainan Coalfield. 
(3) Polarized light microscopic analysis of Ty coal and fluorescence analysis of the limestone and mudstone on the coal seam roof and floor suggested that the peat bog existing during the formation of the Ty coal seam was strongly affected by the presence of seawater. Also, the degree of mineralization of the coal seam was relatively high, which is indicative of reducing conditions existing at the time of coal formation in a coastal environment.

(4) AFM observations indicated that nano-scale pores developed on the surfaces of organic matter and minerals of the Ty coal, and these sites were conducive to the adsorption of $\mathrm{Ge}$ on the organic matter, clay minerals and limonite.

(5) The organic carbon isotope values for the Ty coal samples ranged from $-24.1 \%$ o to $-23.8 \%$, with an average value of $-24.0 \%$, and this is a reflection of the strong biochemical activity experienced by the Ty coal during formation, and the significant exchange processes making the $\delta^{13} \mathrm{C}$ values lighter. The Ge content in Ty coal had negative correlations with volatile matter and ash yield.

Acknowledgements We acknowledge support from the Public Welfare Geological Work Project of Anhui Province (2016-g-333), National Natural Science Foundation of China (No. 41502152) and the Anhui Postdoctoral Science Foundation (2015M571940).

Open Access This article is licensed under a Creative Commons Attribution 4.0 International License, which permits use, sharing, adaptation, distribution and reproduction in any medium or format, as long as you give appropriate credit to the original author(s) and the source, provide a link to the Creative Commons licence, and indicate if changes were made. The images or other third party material in this article are included in the article's Creative Commons licence, unless indicated otherwise in a credit line to the material. If material is not included in the article's Creative Commons licence and your intended use is not permitted by statutory regulation or exceeds the permitted use, you will need to obtain permission directly from the copyright holder. To view a copy of this licence, visit http://creativecommons. org/licenses/by/4.0/.

\section{References}

Dai SF, Ren DY (2007) Effects of Magmatic Intrusion on Mineralogy and eochemistry of Coals from the Fengfeng-Handan Coalfield, Hebei, China.Ener Fuels 21:1663-1673

Dai SF, Zhou YP, Zhang MQ et al (2010) A new type of Nb (Ta)$\mathrm{Zr}(\mathrm{Hf})-\mathrm{REE}-\mathrm{Ga}$ polymetallic deposit in the late Permian coalbearing strata, eastern Yunnan, southwestern China: possible economic significance and genetic implications. Int J Coal Geol 83(1):55-63

Dai SF, Ren DY, Chou C-L et al (2012a) Geochemistry of trace elements in Chinese coals: a review of abundances, genetic types, impacts on human health, and industrial utilization. Int $\mathbf{J}$ Coal Geol 94:3-21

Dai SF, Wang XB, Seredin VV et al (2012b) Petrology, mineralogy, and geochemistry of the Ge-rich coal from the Wulantuga Ge ore deposit, Inner Mongolia, China: new data and genetic implications. Int J Coal Geol 90-91:72-99

Dai SF, Ren DY, Zhou YP et al (2014) Genetic types, modes of occurrence, and utilization evaluation. J China Coal Soc 39(8): 1707-1715

Dai SF, Liu JJ, Ward CR et al (2015) Petrological, geochemical, and mineralogical compositions of the low-Ge coals from the Shengli Coalfield, China: a comparative study with Ge-rich coals and a formation model for coal-hosted Ge ore deposit. Ore Geol Rev 71:318-349

Dai SF, Chekryzhov IY, Seredin VV et al (2016) Metalliferous coal deposits in East Asia (Primorye of Russia and South China): a review of geodynamic controls and styles of mineralization. Gondwana Res 29(1):60-82

Goldschmidt V (1935) Rare elements in coal ashes. Ind Eng Chem 27:1100-1102

Goldschmidt V (1937) The principles of distribution of chemical elements in minerals and rocks. The seventh Hugo Müller Lecture, the Chemical Society (London), March 17th, J Chem Soc 102:655-673

Hower JC, O'Keefe JMK, Wagner NJ et al (2013) An investigation of Wulantuga coal (Cretaceous, Inner Mongolia) macerals: paleopathology of faunal and fungal invasions into wood and the recognizable clues for their activity. Int J Coal Geol 114:44-53

Hu RZ, Ye ZJ (1996) The Genesis of Lincang germanium deposit-a preliminary investigation. Acat Mineral Sin 12:97-102

Hu RZ, Qi HW, Bi XW et al (2006) Geology and geochemistry of the Lincang superlarge germanium deposit hosted in coal seams, Yunnan, China. Geochim Cosmochim Acta 70:A269

$\mathrm{Hu}$ GQ, Liu GJ, Wu D et al (2018) Geochemical behavior of hazardous volatile elements in coals with different geological origin during combustion. Fuel 233:361-376

Huang WH, Yang Q, Peng SP et al (2001) Geochemistry of Permian coal and its combustion residues in Huainan Coalfield, China. J China Univ Geosci 12:283-290

Mortlock RA, Froelich PN, Feely RA et al (1993) Silica and germanium in Pacific Ocean hydrothermal vents and plumes. Earth Planet Sci Lett 119:365-378

Pokrovski GS, Schott J (1998) Experimental study of the complexation of silicon and germanium with aqueous organic species: implications for germanium and silicon transport and $\mathrm{Ge} / \mathrm{Si}$ ratio in natural waters. Geochim Cosmochim Acta 62:3413-3428

Qi HW, Hu RZ, Su WC et al (2004) Continental hydrothermal sedimentary siliceous rock and genesis of superlarge germanium (Ge) deposit hosted in coal: a study from the Lincang Ge deposit, Yunnan, China. Sci China Ser D Earth Sci 47:973-984

Qi HW, Hu RZ, Zhang Q (2007a) Concentration and distribution of trace elements in lignite from the Shengli Coalfield, Inner Mongolia, China: implications on origin of the associated Wulantuga germanium deposit. Int J Coal Geol 71:129-152

Qi HW, Hu RZ, Zhang Q (2007b) REE geochemistry of the cretaceous lignite from Wulantuga germanium deposit, Inner Mongolia, Northeastern China. Int J Coal Geol 71:329-344

Qian CS (1988) Discussion on the occurrence regularity of germanium in coal and its development and utilization. Raw Mater Rep 2:14-18

Qing SL (2001) Preservative principals of germanium deposit in Shengli Coalfield of Inner Mongolia and prospecting direction. Coal Geol China 13:18-19

Seredin VV (2003) Anomalous trace elements contents in the Spetsugli Germanium deposit (Pavlovka Brown Coal Deposit) Southern Primorye: communication 1. Antimony. Lithol Miner Resour 38:154-161

Seredin VV, Dai SF (2012) Coal deposits as potential alternative sources for lanthanides and yttrium. Int J Coal Geol 94:67-93 
Seredin VV, Finkelman RB (2008) Metalliferous coals: a review of the main genetic and geochemical types. Int $\mathrm{J}$ Coal Geol 76:253-259

Seredin VV, Danilcheva YuA, Magazina LO et al (2006) Ge-bearing coals of the Luzanovka Graben, Pavlovka brown coal deposit, southern Primorye. Lithol Min Resour 41:280-301

Seredin VV, Dai SF, Sun YZ et al (2013) Coal deposits as promising sources of rare metals for alternative power and energy-efficient technologies. Appl Geochem 31:1-11

Shao L, Wang X, Wang D, Li M, Wang S, Li Y, Shao K, Zhang C, Gao C, Dong D, Cheng A, Lu J, Ji C, Gao D (2020) Sequence stratigraphy, paleogeography, and coal accumulation regularity of major coal-accumulating periods in China. Int J Coal Sci Technol 7(2):240-262

Stach E (1982) Murchison D G. Stach's textbook of coal petrology

Swaine DJ (1990) Trace elements in coal. Butterworths, London, pp $1-278$

Tang XY (2002) Modes of occurrence of trace elements in coal. Coal Geol China 14(s1):14-17

Tang Y, Li R, Wang S (2020) Research progress and prospects of coal petrology and coal quality in China. Int $\mathrm{J}$ Coal Sci Technol 7:273-287
Wang LM (1999) Introduction of the geological feature and explorating of germanium deposit in Xilinguole League, Inner Mongolia. Inner Mong Geol 3:16-21

Wu D, Liu GJ, Sun RY, Chen SC (2014) Influences of magmatic intrusion on the macromolecular and pore structures of coal: evidences from Ramanspectroscopy and atomic force microscopy. Fuel 119:191-201

Yakushevich AS, Bratskaya SY, Ivanov VV et al (2013) Germanium speciation in lignite from a germanium-bearing deposit in Primorye. Geochem Int 51:405-412

Yudovich YE (2003) Notes on the marginal enrichment of germanium in coal beds. Int J Coal Geol 56:223-232

Zhao JY, Tang XY, Huang WH (2002) Abundance of trace elements in coal of China. Coal Geol China 14(s1):5-13

Zhuang XG, Querol X, Alastuey A et al (2006) Geochemistry and mineralogy of the Cretaceous Wulantuga high-germanium coal deposit in Shengli coalfield, Inner Mongolia, Northeastern China. Int J Coal Geol 66:119-136 